\title{
Biyosensörler ve Nanoteknolojik Etkileşim
}

\author{
Zülfü TÜYLEK ${ }^{1 *}$ \\ ${ }^{1}$ İnönü Üniversitesi, Yeşilyurt MYO, Elektronik ve Otomasyon Bölümü, Biyomedikal Cihaz Teknolojisi Programı, \\ Yeşilyurt/Malatya
}

\begin{abstract}
Özet
Bilim dünyası tarafindan geliştirilen teknolojinin ışığında, doğadaki olaylar moleküler boyutta inceleme olanağı kazanmıştır. Bilim dünyasının gelişen olayları giderek daha küçük boyutta gözlemleme ve tanımlama imkânına kavuşması, fizyolojinin ve patolojinin moleküler temellerinin aydınlatılmasını sağlamıştır. Araştırmacılar, moleküler düzeyde biyolojik işlevlere müdahale etme imkânlarını araştırmaktadır. Günümüz bilim dünyasındaki en yeni kavramlardan biri olan biyosensörler, insan sağlığına yeni bir sıçrama imkânı getirmektedir. Bu biyosensörler, biyolojik sistemler ile birleştirilen sensör sistemlerini kapsar. Bu biyosensörler iki ana bölümden oluşur. Bunların birincisi biyolojik algılayıcı elemandır. Diğeri ise fizikokimyasal dönüştürücüdür.

Yaşam ortamında meydana gelen değişiklikleri algılama ve bunlara cevap verme işleyişi, biyosensörlerin gelişiminin temelini oluşturmuştur. Mikroelektronikteki son gelişmeler ve biyolojik moleküllerin olağanüstü duyarlılıktaki yanıt verme kapasitelerinin keşfedilmesi, biyosensör teknolojilerinin hızla gelişmesine neden olmuştur. Nanoteknoloji, tıbbi görüntüleme, farmakoloji, mikrobiyoloji, yara iyileşmesi, dokuların yenilenmesi, bazı kronik hastalıkların tedavisi, aşı ve genetik alanında uygulamaya girmiştir. Nanoteknolojik ürünler; hızlı teşhis ve tanı işlemlerini gerçekleştirmek, kanserin erken safhasında tanılanması, patojenlerin belirlenmesi, detaylı görüntüleme ve enfeksiyonların önlemesi için fayda sağlamaktadır. Sonuç olarak; tıp, eczacılık, gıda güvenliği, çevre kirliliği, askeri uygulamalar gibi çeşitli alanlarda kullanılmak üzere farklı tipte biyosensörler geliştirilmiştir. Bu derlemede, tıbbi ölçüm ve analizlerde kullanılan biyosensörlerin özellikleri belirlenmiş ve literatür de yer alan farklı özelliklere göre sınıflandırmalara yer verilmiştir.
\end{abstract}

Anahtar kelimeler: Biyosensörler, Enzim Sensörleri, Nanoteknoloji, Transduserler.

\section{Biosensors and Nanotechnological Interaction}

\begin{abstract}
In the light of the technology developed by the scientific world, it gained the ability to examine the events in the nature at the molecular level. The world of science has been able to observe and identify developing events at ever smaller dimensions, and to illuminate the molecular bases of physiology and pathology. Researchers are exploring the possibility of interfering with biological functions at the molecular level. Biosensors, one of the newest concepts in today's scientific world, bring a new leap forward in human health. These biosensors area sensor systems that are combined with biological systems. These biosensors consist of two main parts. The first of these is the biological sensor element. The other is physicochemical converter.

Sensing and responding to changes in the environment of living Mechanisms, the basis for the development of biosensors created. Recent developments in microelectronics and the discovery of extraordinarily sensitive response capacities of biological molecules have led to the rapid development of biosensor technologies. Nanotechnology has entered applications such as medical imaging, pharmacology, microbiology, wound healing, tissue regeneration, the treatment of certain chronic diseases, genetic and vaccines. Nanotechnology products; provide benefits for carrying out testing and diagnostic procedures rapidly, diagnosing the cancer in the early stage, identification of pathogens, detailed imaging and preventing infections. Development in the recent year micro-electric field, and the discovery of the high-sensitive response capacity of the biological molecules have led rapid advancements on biosensor technology in many areas of the science. As a result; Different types of biosensors have been developed for use in a variety of fields such as medicine, pharmacy, food safety, environmental pollution, military applications. In this review, characteristics of biosensors that are used in medical measuring and analyzing have been determined and classifications of biosensors according different features that are found in literature are presented.
\end{abstract}

*Sorumlu yazar: zulfu.tuylek@inonu.edu.tr

Geliş Tarihi: 22/03/2017 Kabul Tarihi: 03/07/2017 
Keywords:Biosensor, Enzyme Sensors, Nanotechnology, Transducers.

\section{Giriş}

Doğada yaşam mücadelesi veren canlılar, yaşadıkları ortamlarda belli bir süreç içinde meydana gelen değişimlerin tümünü algılarlar. Yaşamlarını devam ettirebilmek adına bu değişimlere ayak uydurmak zorundadırlar. Canlılardaki bu algılama mekanizması (Göz, Burun, Deri, Dil ve Kulak) araştırmacılar tarafindan örnek alınarak laboratuar ortamında elde edilmeye çalışılır. İşte biyolojik bir olayın elektriksel sinyale dönüşümünün laboratuar ortamında elde edilmesi sonucu biyosensörler elde edilmiştir. Canlılar, yaşam süreci içinde gerçekleşen uyarıların algılanmasını sağlayan biyolojik maddeleri temel parçalarına ayırır. Daha sonra bu parçalar ve aralarındaki ilişkiler bir bütün halinde incelenir. $\mathrm{Bu}$ araştırmalar sonucu elde edilen sistemlerin (biyolojik bir olayın elektriksel sinyale dönüşümü) birleştirilmesi sayesinde biyosensör yapılar oluşur [1]. Günümüzdeki teknolojik gelişmeler sayesinde biyosensörler çok hızlı bir gelişim göstermektedir. Sensör teknolojisinin kimya, biyoloji, malzeme bilimi, mühendislik gibi çalışma alanlarını kapsaması ve bu disiplinlerdeki yeni teknolojilerle güncellenmesi biyosensörlerin gelişimine bariz şekilde katkı sağlamıştır.

Biyosensörler amperometrik, potansiyometrik, piezoelektrik, 1sıl, akustik ve optik sensörler gibi mevcut yapılar sayesinde enzimler, hücreler, mikroorganizmalar, kimyasal reseptörler ve immunolojik ajanlar gibi biyolojik sistemlerin bir araya getirilmesi sonucu ortaya çıkmışlardır [2]. Biyosensörler, canlı vücudunda gerçekleşen (dış etkenlere bağlı olarak) biyolojik bir olayın elektrik sinyali haline dönüştürülmesi şeklinde tanımlanır. Fizik, kimya, biyoloji, biyokimya, mühendislik gibi birçok bilim dalından elde edilen bilgi birikimlerinden yararlanılarak, biyolojik moleküllerin veya sistemlerin seçimlilik özellikleri sayesinde ileri elektronik işlem yeteneklerinin birleştirilmesi sonucu geliştirilir. Biyosensörler, tıp ve eczacılığın yanında birçok farklı endüstriyel alanda kullanılmak üzere geliştirilmiş biyoanalitik cihazlardır.

Biyonsörler, biyolojik analizlerde kullanılan ve farklı özellikteki kimyasal maddelere karşı verilen biyolojik yanıtların optik, 1sıl, elektrik gibi sinyallere dönüştürülmesini sağlar. Biyosensörler, elektronik devrelerin zaman içinde gelişim göstermesi sonucu küçük boyutlu yapılar haline gelmişlerdir. Biyosensörlerin nano boyutlu çalışmalar sayesinde çipler üzerine montajı sağlanmıştır. Bununla birlikte elektronik alanda biyolojik yapıların bulundurulması ve farklı yanıt verme yetenekleri geliştirilmiştir [3]. Biyosensör teknolojisi incelendiğinde nanoteknolojiden etkilendiği görülmektedir. Nanoteknoloji sayesinde boyutları daha küçük, hassas, uzun ömürlü ve ucuz olacak şekilde elde edilir. Biyosensörler yeni gelişen teknolojiler sayesinde gelişmeye devam edecektir.

\section{Biyosensörler}

Canlılar yaşamlarını sürdürebilmek için bulundukları ortamda meydana gelen değişimleri algılayıp en kısa sürede adapte olmak zorundadır. Sergiledikleri bu davranışlar sayesinde, dışarıdan gelebilecek tehlikelere karşı koruyucu kalkan oluşturmak için çoğunlukla saf enzim, doku ve mikroorganizma özelliğine sahip doğal sensörleri kullanırlar [4]. Canlılarda var olan algılama mekanizması birçok bilim adamı tarafından örnek alınarak biyosensörler elde edilmiştir. Yapılan çalışmalar sayesinde elde edilen enzim elektrodu, glukoz ve oksijen içeren biyolojik çözeltiyle temas ettirildiğinde her iki bileşik enzimatik membran içinden geçer. Çözelti içerisindeki elektrot oksijeni kullanarak glukozu glukonik aside oksitler. Bu sayede enzim elektrotu oksijenin kısmi basıncında meydana gelen azalma miktarını ölçer. Biyolojik sensörler bu değişimlerden yararlanarak fiziksel verileri elde eder. Analitlerin (Biyolojik veya biyolojik olmayan uygulamalarda analizi yapılan madde veya materyal), biyolojik algılayıcıların (Enzimler, antikorlar, nükleik asitler (Deoksiribonükleik asit, ribonükleik asit), mikroorganizmalar, hücreler, dokular, yapay biyolojik alıgılayıcılar) ve seçici olarak etkileşimde bulunan fizikokimyasal dönüştürücülerin (Elektrodlar, transistörler, termistörler, optik fiberler, piezoelektrik kristaller) bir araya getirilmesi sonucu fiziksel sinyallerin ölçülmesi sağlanır. Ölçülen bu fiziksel sinyallerden elektriksel sinyaller elde edilir. Bu şekilde çalışma sergileyen yapılar biyosensör olarak adlandırılır [5]. Şekil 1'de biyosensörlerin blok gösterimi verilmektedir. 


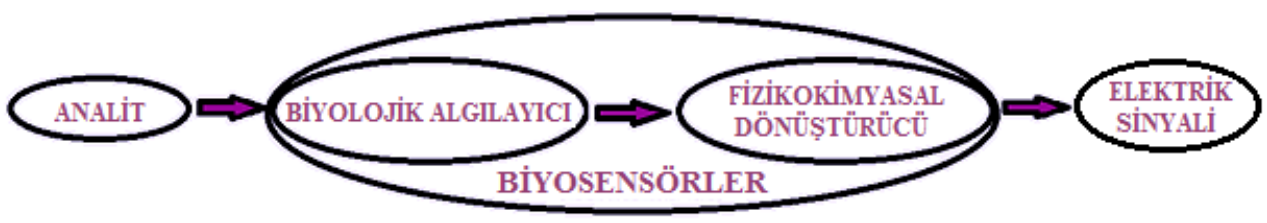

Şekil 1. Biyosensörlerin blok gösterimi

Biyosensörler, biyolojik reaksiyonlarda hedef analit materyalleri denetlemek amaciyla kullanılan ve algılama özelliğine sahip olan cihazlardır. İç içe geçmiş biyokimyasal ve elektrokimyasal özellikteki iki anahtar yapıdan oluşur. Biyokimyasal kısım analiz edilecek maddeyle etkileşime girer ve onun tanınmasını sağlar. Bu işlem sırasında biyokimyasal ürün meydana gelebilir. Biyosensörlerin elektrokimyasal kısmında ise tanıma olayı sonucu elde edilen verinin okunabilir (ölçülebilir) sayısal bir değere dönüşmesi sağlanır [6]. Biyosensörler, biyolojik moleküllerin veya kullanılan düzeneklerin seçimlilik özellikleri ile kullanılan ileri elektronik yöntemlerin işlem kabiliyetlerinin birleştirilmesi sonucu geliştirilen modern yapılar olarak adlandırılır. Günümüz teknolojisi sayesinde geliştirilen ve geniş kullanım alanına sahip olan biyosensörlerin birçok uygulama alanı bulmaktadır. Biyosensörler genellikle biyolojik veya kimyasal etkiye sahip bir maddeye seçici olarak, hızlı ve devamlı bir şekilde reaksiyon göstermesi sonucu işlevlerini yerine getirir [7]. İşlevini yerine getirirken biyoaktif ve biyoalgılama materyaline sahip olmak zorundadır. $\mathrm{Bu}$ materyaller, analitleri tanıyabilmeli ve transdüser ile yakın temas içinde bulunmalıdır. Aksi takdirde biyosensör uygulamalarında elde edilen büyüklükler üzerinde işlem yapılması sırasında sıkıntılar ortaya çıkar. Bu yapılar biyoloji, fizik, kimya, biyokimya gibi bilim alanlarından elde edilen deneyimler sayesinde bilimsel veya teknik açıdan birçok bilim dalının birlikte kullanılması sonucu ortaya çıkmıştır. Elde edilen bu yapıların, uzun depo kararlılığı, kısa analiz süresi, tepkimelerde işlenen maddelerin orijinalliği gibi birçok üstün özelliği bulunur. Yapılan analizlerde tekrarlanabilirlik özelliği yüksek olduğundan tüm laboratuar ortamlarda kolaylıkla uygulanabilir. Bu metodun uygulanması için fazla zamana ihtiyaç yoktur. Yapılan ölçüm işlemleri esnasında işlem basamak sayısı daha az olur. Bu nedenle yapılan işlemler esnasında yüksek fiyatlı cihazlara ve çeşitli kimyevi materyallere gereksinim duyulmaz.

\section{Biyosensörlerin Yapısı ve İşlevleri}

Biyosensörler, biyobileşenlerin (reseptör) ve fiziksel bileşenlerin (transducer) bir araya getirilmesi sonucu ortaya çıkarlar. Reseptörler, biyomoleküler bir yapıya sahip olduğundan biyoreseptör olarak adlandırılır. Biyoreseptörler, analiti algılayabilen biyomoleküller bir yapıya sahiptir. Biyosensörlerin gelişiminde anahtar rolü bulunan biyoreseptörler, analiz edilecek madde ile seçici olarak etkileşim içerisine girebilen oldukça duyarlı biyolojik yapılardır. Biyoreseptör yapılarda, biyolojik moleküller (antikor, enzim, protein, nükleik asitler gibi) veya canlı biyolojik sistemler (hücre, doku ve mikroorganizmalar gibi) kullanılabilir [8]. Günümüzde biyosensörler biyobileşen ve transduser olarak birçok farklı madde ve sistem içerir. Bunların en önemlileri Tablo 1'de verilmiştir.

Tablo 1. Biyosensör bileşen içerikleri [9]

\begin{tabular}{|c|c|c|}
\hline Analit (Örnek) & Biyobilesen (Reseptör) & Sinyali İleten Sistem \\
\hline Metaller & & Elektrokimyasal Es aslı \\
\hline Hormonlar & Enzimler & Elektrokimyasal Es aslı \\
\hline Enzim & Antikoriar & Yan iletken Esash \\
\hline Koenzimler & Hücre & Optik Esasli \\
\hline Substrat & Doku kesitleri & Fotometri Esasli \\
\hline Alativatör & Reseptötler & Flüorometri Esaslı \\
\hline Inhibitör & Mileroorganizmalar & Flü orometri Esash. \\
\hline Antikor - Antijen & Nükleik asitler & PiezoelektrikEs ash \\
\hline Nükleik asit & Lipitler & Kuartz Kristal Mikrobalans \\
\hline Mileroorganizmalar & Hücre organellen & Milerokantileveriar \\
\hline Glikoz & Glikoz okcsidaz & Amperometrik \\
\hline $\mathrm{L}-$ aminoasitler & Horserodis, perolsidaz & Potansiyometrik \\
\hline Herbist & Antibadiler & Piezoelektrik quartz kris tal \\
\hline
\end{tabular}


Biyosensörler, biyolojik bir olayın elektriksel sinyale dönüştürülmesini sağlar. Genel olarak analizi yapılacak olan madde ile isteğe bağlı olarak etkileşime giren biyoaktif bileşenin etkileşmesi sonucu ortaya çıkan sinyali ileten bir iletici düzenekle birleştirilmesi ve ölçüm düzenekleriyle birlikte kullanılması sonucu oluşur. Oluşan sistem özelliklerine bağlı olarak yükseltici, mikroişlemci, dijital görüntüleyici gibi yapılara ihtiyaç duyulduğunda sistem içerisine sonradan dahil edilebilir. Sistem içerisine sonradan dahil edilen bu fiziksel bileşenler, biyobileşenlerin biyolojik fonksiyonlarını ölçebilme özelliğine bağlı olarak fiziksel sinyale dönüştürür. Oluşan biyokimyasal reaksiyon göz önünde bulundurularak uygun fiziksel büyüklük seçilir. Fiziksel büyüklük (transduser) olarak sistem içerisinde kullanılan elektrotlar (İletken çubuk) amperometrik ve potansiyometrik gibi ölçme işlemlerinde kullanılır [10]. Ayrıca bu ölçme işlemleri dışında transistör ve termistör gibi elektronik elemanlar da fiziksel bileşen olarak sistem içerisinde kullanılabilir. Biyosensörlerde, biyoaktif bileşenleri tayin eden maddenin etkileşimi sonucu gerçekleşen sinyalin ölçülmesi ve iletilmesi sırasında elektrokimyasal, optik, kalorimetrik ve piezoelektrik gibi elektronik düzenekler kullanılır. Sistem içerisinde kullanılan bu düzenekler sayesinde uzun süren tahliller daha kısa sürede sonuçlandırılır. Şekil 2'de biyosensör bileşenleri verilmektedir.

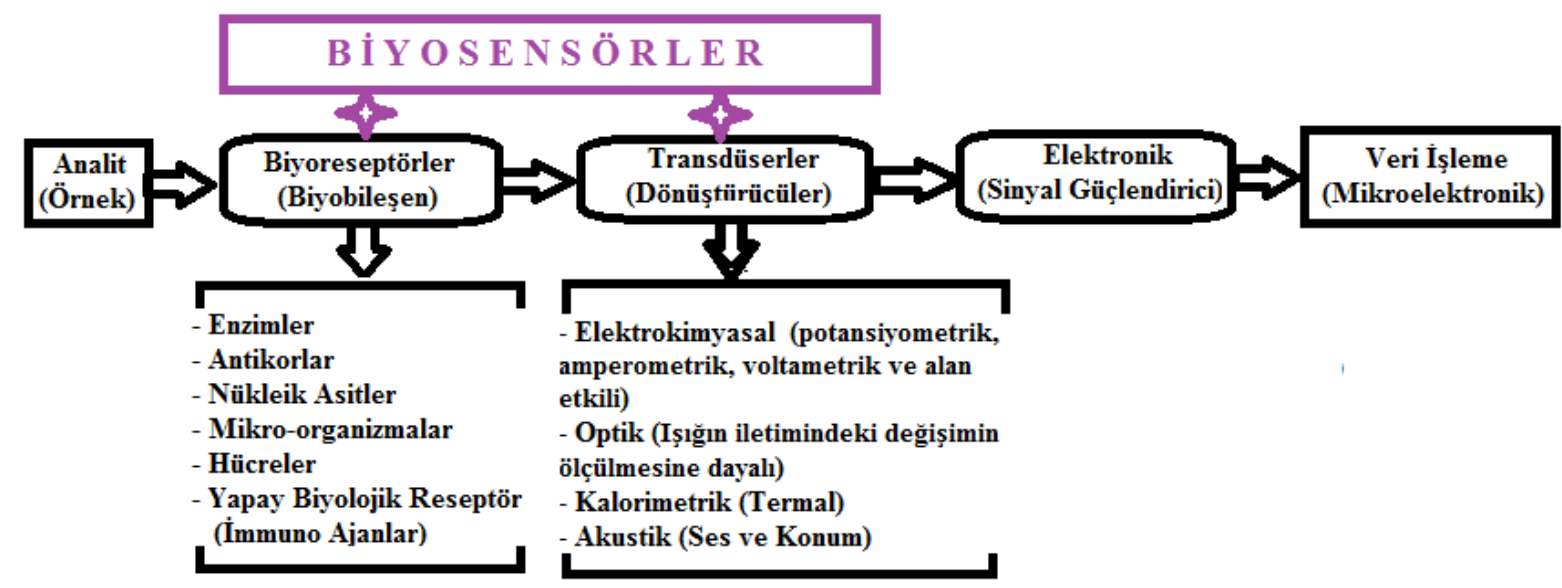

Şekil 2. Biyosensörleri oluşturan bileşenler

Biyosensör uygulamalarında, analiz edilecek madde ve yapılar analit olarak tanımlanır. Biyosensör yapısındaki bileşik veya karışımları oluşturan unsurlar, biyoreseptör olarak adlandırılır. Biyoreseptörler, analit maddeleri olduğundan farklı bir biçime dönüştürür. Bu işlemler sırasında yaygın olarak kullanılan analitler, enzimler ve antikorlardır. Enzim-substrat ve antikor-antijen arasındaki ilişkilerin ilk adımı analitlerin protein moleküllere bağlanmasıdır. Kimyasal bağın hidrolizini katalizleyen enzimler dışındaki esas işi yapan enzimlerin yokluğunda yalnızca tepkime esnasında işlenen maddeler enzime bağlanır. Esas işi yapan enzimlerin varlığında ise tepkime esnasında işlenen maddelerin kimyasal dönüşüme uğraması sonucu gerçekleşir. Son yıllarda geliştirilen katalitik antikorlar yalnız antijenleri benimsemekle kalmaz bunlarla kimyasal tepkimeye giren bir maddeyi, hiçbir değişikliğe uğratmadan, tepkimenin gerçekleşmesini veya tepkime hızının değişmesini sağlar. Protein yapılı küçük maddelerin polimerleşmesi sonucu büyük moleküller oluşur [11]. Ayrıca nükleik asitler ve karbonhidratlar da bir türe özgü gen halkası analizleri ve hücre yüzeyi karakterizasyonu gibi alanlarda kullanılır. Böylece biyosensör uygulama alanları geliştirilir. Biyosensörler için pek çok sınıflandırma yapılmaktadır. Örneğin biyoreseptör (Antikor / antijen etkileşimi, Nükleik asit etkileşimi, Enzimatik etkileşimler, Hücresel etkileşimler, Biomimetrik malzeme etkileşimi) veya dönüştürücü tipine göre (Optik ölçümler, elektrokimyasal, Kütle hassasiyetine dayalı ölçümler) sınıflandırılırlar [12]. Biyosensör sınıflandırılmasında farklı bir bakış açısı ise iletim ve ölçüm sistemleri arasındaki ilişkiye bağlı olarak gerçekleşir. Buna ilişkin yapılan sinıflandırma tablo 2' deki gibidir. 
Tablo 2. Biyosensörlerin, iletim ve ölçüm sistemlerine göre sınıflandırılması

\begin{tabular}{|c|c|}
\hline Biyosensörler & Smuflandurlması \\
\hline E lektrolimyasal E sash Biyosensörler & $\begin{array}{l}\text { - Amperometri Esaslı Biyosens örler (Elehtrotlar) } \\
\text { - Potansiyometri Esaslı Biyosensörler (Elektrotlar) } \\
\text { - Yan İletken (kondüktometri) Es ash. Biyosensötler } \\
\text { (Transistörler) }\end{array}$ \\
\hline OptikE sash Biyosensörler & $\begin{array}{l}\text { - Fotometri Esash Biyosens örler (Optik Lifler) } \\
\text {-Flvorometri Esash Biyosens örler (Optik Lifler) } \\
\text {-Biyolüminesans Es ashı Biyosensörler (Optik Lifler) }\end{array}$ \\
\hline Kalorimetri E sash Biyosensörler & - Termistörler (Is1. İzotermal, Izoperibol) \\
\hline PiezoelehtrikE sash Biyosensörler & -Piezoelektrik Kristaller \\
\hline
\end{tabular}

Transduserler, reseptörlerin oluşturduğu biyolojik reaksiyonları ölçen ve fiziksel bir sinyale dönüştüren yapılardır. Analitin tanınmasından sonra fiziksel ve kimyasal değişim algılanır, ölçülür ve dijital sinyallere dönüştürülür. Biyokimyasal tepkimeler göz önüne alınarak transduser seçimi yapılır. Enzim elektrodlar, amperometrik ve potansiyometrik ölçme işlemlerinde kullanılan hedef bir maddedir. Biyosensör yapısında bir enerji biçimini başka bir enerji biçimine dönüştüren cihazlar (Transdüserler), elektrokimyasal (Amperometrik, voltametri, potensiyometrik, kapasitif, iletken, impedans olanlar dahil), optik (Yüzey plazmon rezonans, emilim, kimyasal 1şıldama, biyolojik 1ş1ldama, flüoresans, optik fiber olanlar dahil), piezoelektrik (kuartz kristal mikrobalans, yüzey ses dalgası), kalorimetrik ve manyetik özellikler sergiler [13]. Biyosensörler günümüzde ağırlıklı olarak biyomedikal alanlarda teşhis amaçlı kullanılır. Hiç şüphesiz biyomedikal cihaz teknolojisi biyosensör için en iyi uygulama alanlarından biridir. Biyomedikal alanında uygulama imkânı bulan ilk sensör enzim biyosensörüdür. Ticari amaçla üretilen ilk biyosensör şeker hastalığı teşhisi, kan ve idrarda glukoz tayini için geliştirilen glikoz oksidaz elektrotudur. Bu enzim sensörlerine vücuttaki glukoz, üre, şeker gibi biyolojik ürünlerin takip edilmesi, kanserlerin izlenmesi ve mikropların sebep olduğu vakaların tespiti amacıyla sıklıkla başvurulur [14]. Biyosensör teknolojisinin tarihi gelişimine bakıldığında bu alandaki ilk çalışmanın enzim sensörleriyle başladığı görülmektedir. Bu alanda yapılan çalışmalar sayesinde, oluşturulan yeni analitik sistemler, biyolojik sistemin (enzim) yüksek seçiciliği ve fiziksel sistemin (sensör) tayin duyarlılığı gibi birçok biyolojik parametreye yönelik uygulamaların yapılmasıyla çeşitli tipte biyosensörler geliştirilir. Şekil 3'de enzim biyosensörünün genel görünümü verilmektedir.

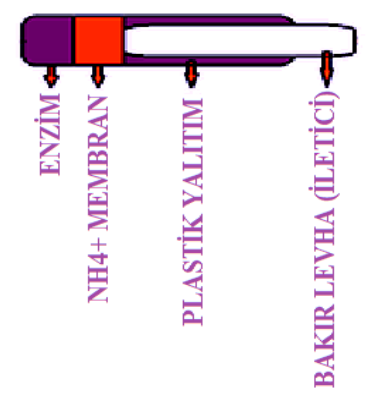

Şekil 3. Enzim biyosensörünün genel görünümü

Enzim sensörünün şematik görünümü incelendiğinde genel çalışma prensibi anlaşılabilir. Bunun için enzim veya enzimlerin immobilize edilmiş biyoaktif tabakasındaki olayların yakından incelenmesi gerekir. Enzim elektrotundaki biyoaktif tabaka, enzimi katalizleyip reaksiyona sokan uygun bir iletim ve ölçüm sistemi ile birleştirilir. İletim sistemleri, biyoaktif tabakada meydana gelen enzimatik reaksiyon sonucu substrat, kosubstrat konsantrasyonundaki azalış veya artış miktarına uygun olarak seçilir. Konsantrasyonların hızlı bir şekilde dengeye kavuşması için difüzyonu azaltmak amacıyla biyoaktif tabaka kalınlığı mümkün olan en ince hale getirilir. Biyoaktif tabakada sabit enzim tepkimesi şeklinde gerçekleşen madde konsantrasyonu için ölçüm çözeltisinin yeterli miktarda karıştırılması 
gerekir. Kullanılacak olan doğal ölçüm çözeltisi, biyoaktif tabaka ve biyoaktif tabaka-iletici ara yüzeyinde oluşan konsantrasyondan farklılık gösterir. İletici sistemin ölçeceği sinyal, biyoaktif tabakailetici ara yüzeyindeki oluşan konsantrasyonlarla ilişkilidir [15]. Enzim sensörleri genel olarak, biyoaktif tabaka, transduser (iletici) ve ölçüm sisteminden oluşmaktadır. Biyosensörlerin diğer sensörlerden farkı biyoaktif tabaka üzerinde biyomolekül olarak enzim materyalinin bulunmasıdır. Buna karşılık diğer biyosensörlerde olduğu gibi biyoaktif tabakanın iç ve dış yüzeyindeki ince zar, iletici ile ölçüm sistemleri arasındaki sinyal yükselten devreler, mikroişlemciler, ölçüm sistemi ile bağlantılı kaydediciler veya bilgisayar sistemlerine ihtiyaç duyulduğunda sonradan dâhil edilebilir [16]. Temel bilimlerdeki gelişmeler enzimlerin ve diğer biyolojik materyallerin işlevlerini çok daha ayrıntılı bir şekilde ortaya çıkarılmasına imkân sağlar. Bu gelişmeler sonucu farklı biyolojik materyaller ve iletim düzenekleri birleştirilerek yeni özelliklere sahip biyosensör yapılar elde edilir. $\mathrm{Bu}$ alanda hangi temel iletim sistemi uygulanmış olursa olsun elektrokimyasal esaslı biyosensör kullanımı tartışmasız bir üstünlüğe sahiptir [17]. Pratikte enzim elektrotlarının kullanım sahaları oldukça fazladır. Tercih edilmelerindeki en önemli faktör canlı sistemler sayesinde her türlü maddenin doğrudan veya dolaylı yollarla analiz işleminde kullanılacak bol miktarda enzimin bulunmasıdır. Bilinen veya bilinmeyen enzimlerin potansiyel varlığı, yüzlerce enzim preparatının bulunabilmesi ve sayılarının her geçen gün artması enzim sensörlerinin tartışmasız üstünlüğünün devam edeceğini göstermektedir.

\section{Biyosensörlerin Tasarımı}

Biyosensör tasarımı esnasında temel olarak kullanılan ileri teknolojiler, örnekler, çalışma koşulları ve elde edilen sonuçlar göz önünde bulundurulur. Bunlarla ilgili veriler Tablo 3'de verilmiştir [18].

Tablo 3. Biyosensör tasarımında kullanılan önemli unsurlar

\begin{tabular}{l|l|l|l}
\hline \multicolumn{5}{c}{ BIYOSENSÖR } \\
\hline Kullanılan Teknolojiler & \multicolumn{1}{c}{ Analitler } & \multicolumn{1}{c}{ Çalı̧̧ma Koşulları } & \multicolumn{1}{|c}{ Elde Edilen Sonuç } \\
\hline - Kimya, Biyokimya & - Katı & - Çevrim içi & - Seçicilik \\
- Biyoloji, Moleküler & - Siv1 & - Gerçek zamanlı & - Duyarlılık \\
Biyoloji & - Gaz & - Sürekli veya Kesikli & - Ölçüm aralığı ve \\
- MEMS, NEMS, & - Karışım & - Tek veya çoklu & süresi \\
Mikroakıșkan & (Organik ve & hedefler & - Tekrarlanabilirlik \\
- Nanotüp, Nanotel, & inorganik & - Otomatik veya yarı & - Hız \\
Nanopartikül & materyaller) & otomatik & - Maliyet \\
- Enstrümantasyon & & - Tezgah üstü veya & - Tutarlılık \\
& & taşınabilir & - Kararlılık \\
& & - Sahada veya & \\
& & laboratuarda &
\end{tabular}

Kullanılan analitler, birçok bilinen, bilinmeyen, organik ve inorganik materyallerden oluşur. $\mathrm{Bu}$ nedenle analitlerin konsantrasyonu önemlidir. Hedef analitlerin ayrıştırılması sonucu belirginlik sağlanır. Böylece konsantrasyon alt tespit limiti iyileştirilerek arzu edilen değere ulaşılır. Bunun için genellikle filtrasyon, santrifüj ve manyetik imüno-ayrıştırma metodları kullanılır. Manyetik imünoayrıştırma, hızlı, kolay ve otomatik bir uygulama olduğundan biyosensör çalışmaları esnasında tercih edilir. Ayrıştırma metodu uygulamalarında, doğal mıknatıs veya elektro-mıknatıs kullanıldığında manyetik nanopartiküller ve mikropartiküller manyetik olarak manipüle edilebilir. Manipüle edilmiş hücreler, bir manyetik ortam içerisinde kaldığında seçilebilir, ayrıştırılabilir ve sıralanabilir özelliğe kavuşur [19].

Biyosensörlerde belirlilik veya seçicilik performans değerlendirmesinde kullanılan en önemli kriterlerdir. Biyosensörün sadece analit maddeye olan ilgisi özgünlüğünün belirtisidir. $\mathrm{Bu}$ nedenle başka reaktiflere ilgi göstermez ve hatalı sonuç vermez [20]. Biyosensör çıkış sinyalindeki değişimin hedef analit konsantrasyonundaki değişime oranlanması hassaslığının ölçüsünü belirler. Sinyaldeki değişim biyosensörün farklı konsantrasyonlarda hedef analit içeren standart bir çözeltiye maruz bırakılması sonucu gözlemlenebilir. Farklı biyoalgılama materyalleri ve dönüştürme cihazlarına bağlı olarak bir biyosensörün hassaslığını etkileyen birçok faktör bulunmaktadır. Biyosensörün hassaslı̆̆ının her zaman aynı kalması ve güvenilir sayısal sonuçlar vermesi beklenir. Elde edilen sonuçların doğruluk oranının yüksek olması gerekir [21]. 
Biyosensörün tespit süresi, örnekleme aşamasından sonuçların görüntülendiği ana kadar geçen süredir. Bazen cevaplama ve sıfirlama süresi de bu hesaplamaya dâhil edilir. Cevap süresi, bir biyosensör ölçüm sinyalinin bir denklem içinde elde edilmesi için geçen zamandır. Sıfırlanma süresi, bir biyosensörün bir sonraki örneğin kullanıma başlama aşamasına kadar gerek duyulan hazırlık süresidir. Biyolojik örneklerde ve biyoalgılama materyallerinde büyük değişkenlik beklendiğinden biyosensör değerlendirmelerinde tekrar edilebilirlik ve yeniden üretilebilirlik önemlidir. Biyoalgılama materyalleri, zamanla 1sıdan, nemden, $\mathrm{pH}$ ve diğer faktörlerden etkilenir. Bu ortamlarda bozulan organik materyallerin kullanım ömürleri dikkat edilmesi gereken önemli bir diğer faktördür. Gerçekte, bir biyosensörün standart örnek değişikliklerine cevap sinyali, kullanılan biyoalgılama materyallerine bağlı olarak aylar, günler hatta saatlerle ifade edilebilir [22].

\section{Nanoteknoloji ve Biyosensörler}

Nanoteknoloji, maddeyi nano boyutlarda, yani atomik, moleküler ve supramoleküler düzeydeki yapılar seviyesinde denetlenmesi yoluyla yeni malzeme, cihaz ve düzeneklerin tasarlanmas1 ve üretilmesi işlemlerini konu alan bir teknoloji bilimidir. Nanoteknoloji malzemelerin atomik ve moleküler düzeyde işlenmesi ile uğraşır. Bu çalışmalarda elde edilen özellikler sayesinde, istenen işlevleri yerine getirebilen, insan eliyle tasarlanabilen ve moleküler/atomal düzeyde kontrol edilebilen, hiç bilmediğimiz yeni malzemeler, yapılar, organizmalar, sistemler ve cihazların geliştirilmesi sağlanır. Nanoteknolojinin sağlık alanındaki işleyişini incelediğimizde, ilaç geliştirme, teşhis, tedavi, hastalık ve dıştan bir etki sonucu oluşan organ ya da doku yapısını veya biçimini bozmaya yol açan yaralanmaların önlenmesi, ağrının kontrolü, insan sağlığının korunması ve geliştirilmesi, su dekontaminasyonu (Nesne ve canlı dokulardan patojen mikroorganizmaların dezenfeksiyon, sterilizasyon, temizlik ve/veya antisepsi ile uzaklaştırılması ), bilgi ve iletişim teknolojileri, daha hafif ve dayanıklı malzemelerin üretimi gibi birçok alanda önemli katkılar sağladığı görülmektedir [23].

Nanoteknoloji ayrıca farmakoloji ve ilaç dağıtım sistemleri, hasta takip cihazları ve rejeneratif bilimlerdeki gelişmeler sayesinde ağırlık kazanmıştır [24]. Nanoteknoloji sayesinde geliştirilen bu ürünler kullanılarak, ilaçlar hedef doku ve hücrelere taşınmakta, hasta dokular onarılabilmekte, tıkanan damarlar açılabilmektedir [25]. Sağlık alanında birçok soruna çözüm bulan nanoteknoloji, kullanım alanlarındaki artışa paralel olarak önemini giderek artırmaktadır.

Nanoteknoloji kullanılarak üretilen biyosensör MEMS/NEMS/BioNEMS (mikro, nano veya biyonano elektromekanik sistem), nanoteknoloji ve biyoteknoloji alanında elde edilen gelişmelere paralel olarak daha fazla özelliğe sahip olması beklenmektedir. Modern zaman biyosensörleri olarak adlandırılan, nanoteknoloji ve chip teknolojisi kullanılarak geliştirilen yeni nesil biyosensörler sayesinde sonuçların daha kolay izlenmesi ve değerlendirilmesi sağlanır. Bu teknoloji sayesinde, biyoçip yerleştirilen bireyde oluşacak varyasyonların bireyin hastaneye gitmeden takibini mümkün kılacaktır. Ayrıca, moleküllerin temel yapılarını çoğaltma ve görüntüleme yöntemlerinin hızla gelişmesi, nanoteknoloji ile birlikte değerlendirilmesi, nükleotit esaslı biyosensörlerin kullanım alanlarının daha da yaygınlaşmasına neden olacaktır [26, 27].

Sağlık alanında kullanılan nano boyutlu biyosensörler ilk olarak Dr. Meyyappan tarafından yarı iletken biçiminde tasarlanmış ve küçük moleküllerin büyük moleküllere dönüştürülmesi sayesinde karbon nanotüp yapılar incelenmeye başlanmıştır [28]. Yapılan araştırmalar sonucu karbon nanotüp yapılar biyoalgılayıcı ve elektronik parçaların küçültülmesi çalışmaların eşlenmesi biyolojik sistemlerdeki elektrik veya elektrokimyasal sinyallerin tanınması ve okunabilmesini sağlar [29]. Tıp alanında gerçekleştirilen bu nanoteknolojik çalışmalar, nanotıp olarak adlandırılır. Tıp alanında nanoteknolojinin kullanılması sayesinde hücre fonksiyonları kontrol altında tutularak hastalıkların önlenmesi sağlanır. Ayrıca erken teşhis ve tedavi, yara iyileşmesi, vücudun moleküler bilgilerinin kullanılabilmesi, sağlığın geliştirilmesi ve korunması gibi moleküler araçların üretilmesi de sağlanır [30]. Günümüzde kullanılan tıbbi yöntemler hücre düzeyinde etkili olamadığından, bazı hastalık ve yaralanmaların teşhis ve tedavisinde güçlük yaşanmaktadır. Bu amaca yönelik nanoteknoloji kullanımı sonucu, biyomedikal ve tıp alanlarında akıllı ilaç taşıyıcıları, tıbbi görüntüleme araçları, biyosensörler, nanomakineler (biyorobotlar), vücut içerisine ve canlı dokulara yerleştirilen cansız maddeler ve yapay doku materyalleri geliştirilmektedir. Ayrıca nükleik asit analizleri, biyolojik bilginin bilgisayar yardımıyla incelenmesi ve işlenmesi, farklı türlerin yapısal ve işlevsel uygulamaları için DNA 
çiplerinin nanofabrikasyonu, kök hücre bazlı doku mühendisliği (Organ ve doku nakli) uygulamaları ve nanocerrahi girişimler uygulanabilmektedir [31].

Günümüzde nanotıp alanı, özellikle belirli doku ve organları hedef alan nanorobotlar ve sağlıklı hücreye zarar vermeden hedefe yönelik ilaç verebilen yapıların geliştirilmesi sayesinde birçok hasta için umut ışığı olmaktadır. Günümüzde ilaç salan sistemlerin en büyük problemi, ilacın istenilen yere ulaşımının sağlanmasıdır. Bu zorluk, nanoküreler içerisine hapsedilmiş ilaçların hedeflenen dokuya ulaştırılması esnasında daha belirgin olarak karşımıza çıkmaktadır. Vücut içerisine alınan nanoküre yabancı cisim olarak algılandığından bağışıklık sistemi tarafından yok edilmeye çalışılır. Bunun için nanoküreler biyouyumlu polimerlerle kaplanarak bağışıklık sisteminin etkisinden uzak tutulur. Böylece nanokürenin hedef hücreye ulaşımı sağlanır [32]. İlaç taşıyıcı sistemler sayesinde canlılarda çeşitli biyomoleküllerin tanınması ve istenilen şekilde cevap verilmesi mümkün olmaktadır. $\mathrm{Bu}$ yaklaşım sayesinde özgül DNA dizilerini veya herhangi bir serum biyomolekülünü tanımak, sisteme odaklanma süresini saptamak ve nanoteknolojik araçların yapımının gerçekleşmesi mümkün olur [33]. Benzer şekilde reseptörler aracılığıyla, vücuda giren antikorları zararsız duruma getirmek için organizmanın çıkardığı maddelerle veya biyokimyasal usullerle çeşitli hücre içi ve hücre dışı olayları algılayabilen ve tanıdığı bölgede ilaç salınımı yapabilen, olağanüstü katalitik aktiviteye sahip moleküllerin etkinliği veya mekanik bir etkileşimde bulunabilen nano yapılar konusunda araştırmalar devam etmektedir. Nanoteknoloji alanının tıp dünyasına getirdiği en önemli yenilik kanser oluşumu, damar sertleşmesi, yeni damarlanma ve benzeri birçok patolojinin görüntülenmesi, erken teşhis aşamaları ve takibi gibi işlemlerde gelişmiş görüntüleme yöntemlerinin kullanılmasıdır [34]. Radyolojide teşhis amacıyla kullanılan X ışılları, takip edilebilen nanoparçacıkların doku çeşidine, hücre çeşidine, belirli bir kimyasal bağlanma çeşidine ve hatta reseptörlerin alt ünitelerine orijinallik gösterecek şekilde hedeflenebilmesi, gelecekte yeni görüntüleme teknolojilerinin uygulanmasına imkân sağlayacaktır [35].

\section{Nanoteknolojinin Biyosensörlerde Kullanılma Nedenleri [1]}

- Doğadaki büyük boyutlu yapılar yerine nano boyutlu yapılarla çalışma imkânına kavuşmak.

- Uygulamalarda kullanılan nano yapılı malzemeler sayesinde yüksek duyarlılık sağlamak.

- Biyosensörlere nano yapılı elektronik parçacık eklendiğinde bellek ve işlem yetenekleri artar.

- Karmaşık yapılı nano moleküllerin analizlerini kolaylaştırır.

- Çeşitli kimyasal ajanların, mikroorganizmaların ve minerallerin teşhisini mümkün kılar.

- Yüksek yüzey alanı/hacim oranına sahip kablo kullanımı sayesinde yüksek seçimlilik sağlar.

- Nanoteknolojik ürünler çalışma esnasında az enerjiye ihtiyaç duyarlar.

- Nanoteknoloji ile üretilen biyosensörlerde difüzyon problemi gözlenmez.

- Biyosensörlerin daha uzun ömürlü olmaları sağlanır.

- Araştırmacılara canlı hücrelere zarar vermeden çalışma imkânı sunar.

\section{Sonuç ve Öneriler}

Doğadaki canlılar hayatlarını devam ettirebilmek amacıyla çevrelerindeki değişimleri hızlıca algılayıp bunlara adapte olmak durumundadır. Canlıların yaşadığı çevrede ya da kendi içlerinde meydana gelen değişimleri algılama gücü, araştırmacıların ilgisini çeken ve onlara ilham kaynağı olan önemli bir unsur olmuştur. Kusursuz işleyişe sahip olan biyolojik sistem ile teknolojinin birleşmesinin ürünü olan biyosensörler günümüzde göz kamaştırıcı bir seviyededir. Hiç şüphesiz, gerek biyolojide her geçen gün yeni bir bilginin ortaya çıkması gerekse teknolojideki gelişmelerin hız kesmeden devam etmesi, yeni biyosensörlerin çok yakın zamanda geliştirileceğinin habercisidir. Bilim adamları bulunduğumuz yüzyılda nanoteknoloji sayesinde ileri teknolojiye sahip birçok biyosensör üretmekte ve yeni özellikler kazandırmak için çalışmalar yapmaktadır. Biyosensörler, analitin alınması ve sonuçların elde edilmesi arasında geçen süreyi oldukça kısaltmaktadır. Nanoteknoloji ile üretilen biyosensörler daha az analite ihtiyaç duyulmakta ve aynı zamanda yüksek düzeyde duyarlılık ve özgüllüğge sahip olmaktadır. Ölçüm düzeneklerinin otomasyon sistemine uygun ve taşınabilir olması değişik sektörlerde kullanılmasına imkân sağlar. Biyosensörlerin geleceği ise üretim maliyetine ve aktif kullanımına bağlıdır. 
Biyosensörlerin ticarete dönüştürülmeleri, üretici firmalar veya ülkeler adına önemli kazançlar sağlarken, satın alan ülkeler ise büyük miktarda paraları üretici ülkelere ödemek zorunda kalacaklardır. Bu gelişmelerin dışında kalmamak için gelişen teknolojinin nimetlerinden üretici olarak faydalanabilmek gerekmektedir. $\mathrm{Bu}$ amaçla ülkemizde biyosensör konusunun daha sık gündeme getirilmesi ve devlet tarafından daha çok desteklenmesi şarttır.

\section{Kaynaklar}

1. Bulut Y. 2011. Biyosensörlerin Tanımı ve Biyosensörlere Genel Bakış, 6th International Advanced Technologies Symposium (IATS’11), 16-18 Mayıs, Elazığ, Türkiye.

2. Blum L.J., Coulet P.R. 1991. Biosensor Principles and Applications, CRC Press, Boca Raton.

3. Ratner B.D., Hoffman A.S., Schoen F.J., Lemons J.E. 1996. Biomaterials Science, Academic Press, San Diego.

4. Gümüşderelioğlu M., Karakeçili Gönen A. 2013. Nanotıp ve Nano Robotlar, Bilim ve Teknik Dergisi, 20-21.

5. Aykut U., Temiz H. 2006. Biyosensörler ve Gıdalarda Kullanımı, Gıda Teknolojileri Elektronik Dergisi, 3: 51-59.

6. Coulet P.R., 1991. What is a Biosensor? Chapter 1; Biosensor Principles and Applications, Ed: Blum, L. J. Coulet, P. R, Marcel Dekker Inc., New York, 1-6.

7. Patel P.D. 2002. (Bio)sensors for Measurement of Analytes Implicated in Food Safety: A review, TrAC Trends Anal. Chem., 21: 96-115.

8. Scott A.M., Jedd D., Wolchok J.D., Old L.J. 2012. Antibody Therapy of Cancer, Nature Reviews, 12: 278-287.

9. Akbayırlı P., Akyılmaz E. 2007. Activation-based Catalase Enzyme Electrode and Its Usage for Glucose Determination, Analytical Letters, 40: 3360-72.

10. Zhou Y.L., Zhi J.F. 2006. Development of An Amperometric Biosensor based on Covalent Immobilization of Tyrosinase on a Boron-doped Diamond Electrode, Electrochemistry Comunications, 8: 1811-1816.

11. Kindschy L.M., Alocilja E.C. 2004. A Review of Molecularly Imprinted Polymers for Biosensor Development for Food and Agricultural Applications, Trans. ASAE, 47: 1375-1382.

12. Gutes A,, Cespedes F,, Alegret S., Del Valle M. 2005. Determination of Phenolic Compounds by A Polyphenol Oxidase Amperometric Biosensor and Artificial Neural Network Analysis, Biosensors and Bioelectronics, 20 (8): 1668-1673.

13. Şerbetçi Z., Alkan C. 2008. 4-(1h-İmidazo[4,5-F][1,10]Fenantrolin-2-İl)-N,N'Dimetilbenzenamin Ligandı ve Metal Komplekslerinin Sentez ve Karakterizasyonu, Firat Üniversitesi Fen ve Müh. Bilim Dergisi, 20 (1): 91-97.

14. Rainina E.I., Efremenco E.N., Varfolomeyev S.D., Simonian A.L. 1996. The Development of A New Biosensor based on Recombinant E. coli for the Direct Detection of Organophosphorus Neurotoxins, Biosens Bioelectron, 11: 991-1000.

15. Turna Ö. 2006. Aminoasit Biyosensörlerinin Geliştirilmesi, Yüksek Lisans Tezi, Ondokuz Mayıs Üniversitesi, Fen Bilimleri Enstitüsü, Samsun.

16. Dinçkaya E. 1999. Biyosensörler, Ege Üniversitesi Fen Fakültesi, Bask1 Atölyesi, İzmir.

17. Putzbach W., Ronkainen N.J. 2013. Immobilization Techniques in the Fabrication of Nanomaterial Based Electrochemical Biosensors: A Review, Sensors, 13: 4811-4840.

18. Ferrari M., Bashir R., Wereley S. 2007. BioMEMS and Biyomedical Nanoteknology, Springer USA. 
19. Tibbe A.G., de Grooth B.G., Greve J., Dolan G.J., Rao C., Terstappen L.W. 2002. Magnetic Field Design for Selecting and Aligning Immunomagnetic Labeled Cells, Cytometry, 47: 163-172.

20. Singh N., Manshian B., Jenkins G.J.S., Griffiths S.M., Williams P.M., Maffeis T.G.G et al. 2009. Nanogenotoxicology: The DNA Damaging Potential of Egineered Nanomaterials, Biomaterials, 30 (23-24): 3891-914.

21. Ng H.T., Li J., Smith M.K., et al. 2003. Growth of Epitaxial Nanowires at the Junctions of Anowalls, Science, 300: 1249.

22. Rasooly A. 2005. Biosensor Technologies, Methods, 37(1): 1-3.

23. Snejdarkova M., Svobodova L., Gajdos V., Hianik T. 2001. Glucose Biosensors based on Dendrimer Monolayers, J. Mater Sci. Mater Med., 12: 1079-82.

24. D'Souza S.F. 2001. Immobilization and Stabilization of Biomaterials for Biosensor Applications, Appl. Biochem. Biotech., 96: 225-38.

25. Kuruca B., 2012. Nanotıp ve Nanoteknoloji, Net Bilim Dergisi, 14 (1): 17-23.

26. Arlett J.L., Myers E.B., Roukes M.L. 2011. Comparative Advantages of Mechanical Biosensors, Nat. Nanotechnol., 6: 203-15.

27. Pan Y., Sonn G.A., Sin M.L., Mach K.E., Shih M.C., Gau V., Wong P.K., Liao J.C. 2010. Electrochemical Immunosensor Detection of Urinary Lactoferrin in Clinical Samples for Urinary Tract Infection Diagnosis, Biosens Bioelectron, 26: 649-54.

28. Noh J., Park S., Boo H., Kim H.C., Chung T.D. 2011. Nanoporous Platinum Solid-state Reference Electrode with Layer-by-layer Polyelectrolyte Junction for $\mathrm{pH}$ Sensing Chip, Lab. Chip., 11: 664-71.

29. Tascaa F., Ludwig R., Gortona L., Antiochia R. 2013. Determination of Lactose by a Novel Third Generation Biosensor based on a Cellobiose Dehydrogenase and Aryl Diazonium Modified Single Wall Carbon Nanotubes Electrode, Sensors and Actuators B,177: 64-69.

30. Langer R., Weissleder R. 2015. Nanotechnology, JAMA, 313 (2): 135-136.

31. Manchester M., Singh P, 2006. Virus-based Nanoparticles (VNPs): Platform Technologies for Diagnostic Imaging, Adv. Drug. Deliv. Rev., 58: 1505-22.

32. Kocaefe Ç. 2007. Nanotıp: Yaşam Bilimlerinde Nanoteknoloji Uygulamaları, Hacattepe Tıp Dergisi, 38 (1): 33-8.

33. Staggers N., McCasky T., Brazelton N., Kennedy R. 2008. Nanotechnology: The Coming Revolution and Its İmplications for Consumers, Clinicians and Informatics, Nurs Outlook 56 (5): $268-74$.

34. Seimetz D. 2011. Novel Monoclonal Antibodies for Cancer Treatment: The Trifunctional Antibody Catumaxomab (Removab®), Journal of Cancer, 2: 309-316.

35. McGlennen R.C. 2001. Miniaturization Technologies for Molecular Diagnostics, Clin Chem., 47: 393-402. 